Abstracta Iranicacta Iranica

Revue bibliographique pour le domaine irano-aryen

Volume 42-43 | 2021

Comptes rendus des publications de 2019-2020

\title{
John Curtis, "Where Did the Persian Kings Live in Babylon?”
}

\section{Rémy Boucharlat}

\section{(2) OpenEdition}

1 Journals

\section{Édition électronique}

URL : https://journals.openedition.org/abstractairanica/52334

DOI : 10.4000/abstractairanica.52334

ISSN : 1961-960X

Éditeur :

CNRS (UMR 7528 Mondes iraniens et indiens), Éditions de l'IFRI

Référence électronique

Rémy Boucharlat, "John Curtis, "Where Did the Persian Kings Live in Babylon?" », Abstracta Iranica [En ligne], Volume 42-43 | 2021, document 17, mis en ligne le 15 avril 2021, consulté le 28 décembre 2022. URL : http://journals.openedition.org/abstractairanica/52334 ; DOI : https://doi.org/10.4000/ abstractairanica. 52334

Ce document a été généré automatiquement le 28 décembre 2022.

Tous droits réservés 


\section{John Curtis, "Where Did the Persian Kings Live in Babylon?"}

Rémy Boucharlat 


\section{RÉFÉRENCE}

John Curtis, "Where Did the Persian Kings Live in Babylon?" in J. Curtis (ed.). Studies in Ancient Persia and the Achaemenid Period. A collection of essays in memory of the curator and scholar Terence Mitchell, exploring the history and archaeology of Ancient, Persia. Cambridge: James Clarke \& Co., 2020, p. 10-33.

Babylone achéménide est en général jugée peu importante au regard de la cité néobabylonienne. Pourtant les archives privées témoignent de l'activité de cette ville, de même que les nombreuses tombes de cette époque, un trésor d'objets d'argent, des figurines, des sceaux. Les signes de l'intérêt des rois perses eux-mêmes pour Babylone ont été très sous-estimés. À part des fragments d'une stèle reprenant le relief de Bisutun et le Perserbau, petit bâtiment hypostyle à portique datant d'Artaxerxès II, fouillé il y a plus d'un siècle, ce sont surtout d'autres travaux d'architecture, peut-être dès Cyrus, qui montrent l'activité considérable des rois à Babylone. Comme l'a montré Hermann Gasche (dans J. Perrot ed., le Palais de Darius à Suse, 2010), les ensembles palatiaux Palais nord, palais sud qui remontent à l'époque néo-babylonienne, ont été profondément remanié à l'époque perse. Au nord de la ville à Tell Babil, le Palais d'été peut avoir la même histoire ou être seulement d'époque achéménide, il n'est pas possible d'en décider. Deux éléments d'architecture servent de fil conducteur pour identifier ces travaux achéménides, les sols de béton rouge, comme à Persépolis et à Suse, et les plans comportant des "salles à quatre saillants", une tradition élamite connue à Suse.

2 JC propose ici une synthèse très utile dans laquelle il montre bien toutefois les incertitudes qui demeurent et qui appellent d'autres recherches.

\section{AUTEURS}

\section{RÉMY BOUCHARLAT}

UMR 5133 CNRS-Université de Lyon 